\title{
The European Union's Approach towards Child Victim Testimonies in Criminal Proceedings Compared to the Right to Fair Trial: summum ius, summa injuria?
}

\author{
Tomas Königs ${ }^{1}$, Sohail Wahedi ${ }^{1} \&$ Tjalling Waterbolk ${ }^{1}$ \\ ${ }^{1}$ Law Department, Utrecht University, The Netherlands \\ Correspondence: Sohail Wahedi, Law Department, Utrecht University, The Netherlands. E-mail: \\ s.wahedi@students.uu.nl
}

Received: November 1, 2013 Accepted: November 18, 2013 Online Published: November 29, 2013

doi:10.5539/jpl.v6n4p14

URL: http://dx.doi.org/10.5539/jpl.v6n4p14

\begin{abstract}
The concept of a European Union as a common 'area of freedom, security and justice' has offered a fundamental legitimate basis for the 'Europeanisation' of domestic criminal procedures since its anchoring in the Treaty of Amsterdam. Based on this concept, the European legislator is increasingly using different legal instruments to harmonise the law on certain areas in its Member States. As such, the recently adopted Directive provides minimum standards on the rights, support and protection of victims of crime in the European Union. The call for harmonisation as such does not have to be perceived as problematic. This notion is particularly true when harmonising means that victims of crimes can invoke rights to which they are entitled. However, apart from the criticism of Eurosceptics, the 'Europeanisation' of the law is found problematic if it conflicts with the most fundamental principles of European law. In this light, it is very doubtful whether the way in which the Directive provides protection to child victims participating in criminal proceedings is compatible with the right of the accused to a fair trial, which the international community has adopted as a fundamental human right.
\end{abstract}

Keywords: Directive 2012/29/EU, child victims, absent witnesses, fair trial, sole and decisive, European Criminal Law

\section{Introduction}

On the $25^{\text {th }}$ of October 2012, the European Parliament adopted Directive 2012/29/EU establishing minimum standards on the rights, support and protection of victims of crime ('the Directive'). It aims to do exactly what its title reads and offers even greater protection to special victims, such as children and victims of sexual violence. However, a specific provision - Section 24, paragraph 1a - might give rise to some debate. It reads:

'In addition to the measures provided for in Article 23, Member States shall ensure that where the victim is a child: (a) in criminal investigations, all interviews with the child victim may be audiovisually recorded and such recorded interviews may be used as evidence in criminal proceedings'. (Note 1)

This provision aims at protecting children from reliving past trauma, possibly by encountering their sexual assaulter, but might infringe on one of the European Union's ('EU') basic fundamental rights: the right to a fair trial. Namely, Section 6, paragraph 3d of the European Convention on Human Rights ('ECHR' or 'European Convention') gives anyone charged with a criminal offense the right to obtain the attendance of witnesses in court. As a result, the maxim summum ius, summa iniuria - freely translated, 'the greatest right causes the greatest injustice' - might very well apply to the situation before us. Currently, the EU is in the process of acceding to the Council of Europe, which will subject European provisions to the legal norms of the ECHR. This development, as a result, gives the ECHR a significant place in this research.

The fact that these legal provisions might be incompatible with each other gives rise to uncertainty; hence the principle of legitimate expectation might not be followed correctly. It is therefore of the utmost importance to investigate whether there is indeed a conflict between these two legal provisions and why. Consequently, this research focusses on answering the following question: 
Is the right to protection of child victims who are witnesses in criminal proceedings, as secured by Directive 2012/29/EU, compatible with the right to fair trial of suspects under the European Convention on Human Rights and the Charter of Fundamental Rights?

\section{Method}

In discovering which developments and legal provisions preceded the Directive, three UN General Assembly resolutions are analysed as several literary sources referred to them as important international developments leading to the adoption of the Directive. Relevant Council of Europe legislation and recommendations are used as well since this organisation continues to have a strong influence on the creation of EU law. Lastly, an EU Framework Decision on victim protection and several reports from the European Commission on this topic are considered as they give a clear image of EU legislation before the adoption of the Directive.

In providing a clear answer to the research question, the provisions of the Directive are thoroughly analysed. Occasionally, provisions of directives can be invoked directly before national courts. Therefore, relevant European Court of Justice ('ECJ') case law is discussed. Additionally, as the Directive replaces Council Framework Decision on the standing of victims in criminal proceedings, the ECJ case law relating to this Framework Decision, such as Pupino, is analysed as well. These cases provide insight about the scope of the right to fair trial under the Framework Decision.

In determining the compatibility of the Directive with the European Charter of Fundamental Rights ('Charter') literature is used to establishing the scope of the Charter. ECJ case law, which refers to EU general principles, and explanation papers relating to the Charter are included to assess the compatibility of this Directive with the Charter.

To give a clear image of how the European Court of Human Rights ('ECtHR') strikes a balance between the right to fair trial and child victim protection, the ECHR and ECtHR case law is analysed. Cases such as Doorson and Bocos Cuesta indicate an often-changing opinion of the Court. The ruling in the latest case on victim protection and the right to fair trial, Al-Khawaja \& Tahery, provides a fruitful insight to take into account by answering the research question.

This research uses an assessment framework to answer the main question. This assessment framework is operationalized by using both the ECHR and the EU Charter as a yardstick. Their scope of application, content, and effects are taken into consideration. These legal documents are used as the EU Charter is the main human rights source for the EU. The ECHR is included as the Charter is based on it; moreover, the EU is in the process of acceding to the ECHR which will subject EU law to it.

\section{The Background of the Directive}

\subsection{Introduction}

For almost four decades, for the position of victims - the once 'forgotten figure' in the criminal proceedings system - has been subject to an international debate. (Note 2) This debate, which finds its roots in the most egregious experiences of the Second World War, has influenced regional and national legislators in drafting proposals on the position of victims in the criminal proceedings. (Note 3) A variety of countries has developed compensation regimes for victims. (Note 4) Some argue, however, that international law has paid insufficient attention to victims of crimes. Certain fields of international law, including human rights, international criminal law, and humanitarian law, do pay attention to victims of crimes, but the topic is treated differently across these fields. The establishment of various international norms has increased the focus on victims of crimes. These norms are different in nature and were all developed in order to protect a specific group of victims and to create obligations for states to ensure the rights of these groups. (Note 5)

Norms with a universal character can be found in several instruments of the United Nations ('UN'). In light of the Universal Declaration of Human Rights, the UN General Assembly adopted in 1985 for the first time a resolution relating to victims. (Note 6) This resolution was followed by two other resolutions and an international convention. (Note 7)

Regional norms relating to victim protection are found both in Europe and the Americas. (Note 8) European norms are divided into norms drafted by the Council of Europe and those drafted by the EU. Legally binding norms could affect national legal systems on the role victims play in criminal proceedings. (Note 9)

The next paragraph focuses on the European debate on the position of victims, which formed the basis for the Directive. Proposals of the Council of Europe and the EU are discussed as well. 


\subsection{European Norms on Victims of Crime}

After nearly a decade of debate and discussion, the Council of Europe included in 1983 the content of a resolution on victim compensation in the European Convention on the Compensation of Victims of Violent Crimes. (Note 10) The Convention underlined the need for developing victim compensation schemes 'by the State in whose territory (...) crimes were committed (Note 11) and provides minimum provisions to achieve its objectives. Although this Convention did not pursue compensation for all types of victims, the Council of Europe was labelled 'a pioneer' in regulating the needs of victims. (Note 12)

The resolution that led to the establishment of this Convention brought to light large differences between some Members States in the treatment of non-citizens and the lack victim protection in general in other Member States. (Note 13) The harmonisation of the different compensation regimes for victims of crimes has therefore been the main aim of this Convention. (Note 14) The recommended principles of the resolution On the Compensation of Victims of Crime did not lead to a desired compensation for victims in all cases. The European Parliament therefore favoured 'a minimum compensation level', regardless of the victim's background. (Note 15) The discretion given to Member States by the 1977 resolution was replaced by concrete measures the Committee of Ministers proposed in 1983 in its recommendation On Participation of the Public in Crime Policy. The Committee centralised victims' needs by presenting Members States with various measures to meet the needs of victims. (Note 16) In 1985, the Committee drafted a recommendation on the position of victims in criminal proceedings. (Note 17) This was a significant change of focus. The emphasis had shifted from material compensation to the legal position of victims. (Note 18) Furthermore, the concern grew within Europe to protect the so-called 'vulnerable victims' with special needs, such as children and victims of domestic or sexual violence. The individual European countries were, however, careful to avoid infringement of the rights of the defence. (Note 19) In 1985 the Council of Europe recommended its Member States to review their criminal proceedings system in light of the provided guidelines, in order to meet the needs and interests of these vulnerable victims. (Note 20) A set of recommended measures on the needs of victims followed in 1987, (Note 21) which eventually was replaced by the 2006 Recommendation On assistance to crime victims. (Note 22)

As a consequence of the establishment of the area of freedom, security and justice by the Treaty of Amsterdam, the EU increased its focus on the position of victims. The Council of the European Union drafted the Framework Decision on the standing of victims in criminal proceedings ('the Framework Decision') in 2001 and it adopted a Directive relating to compensation to crime victims in 2004. (Note 23) This was the first international legally binding instrument on victim protection and imposed obligatory compliance on the EU Member States. (Note 24) The EU's main incentive to protect victims on a supranational level were the numerous problems relating to cross-border or foreign victims. However, the EU never intended to provide foreign victims with more rights and protection than domestic victims. For this reason, the Framework Decision applied to all victims of crime. Groenhuijsen and Pemberton stated that it differed from existing international instruments due to the different criminal law systems in the Member States. (Note 25) The Framework Decision does take into account these different systems, but it was expected that major changes in the national criminal proceeding laws of the Member States were required to meet the obligations under the Framework Decision. (Note 26) In the years that followed, the European Commission received national reports concerning the implementation of these reports. (Note 27) Most Member States claimed to fulfil their obligations, but the Commission did not share this view. (Note 28) Accordingly, the Commission presented an overview of the shortcomings of the chosen approaches by the Member States. (Note 29) Allegedly, the vague and widely-interpretable standards of the Framework Decision made it hard to assess whether the Member States complied with its obligations. As a result, it is difficult to determine whether this Union instrument has led to the desired and required minimum harmonisation in the field of victim protection. (Note 30)

The Framework Decision was replaced by Directive 2012/29/EU of 25 October 2012. An important basis for establishing this Directive was the 'area of freedom, security and justice' in the EU, which was introduced to 'facilitate the free movement of persons, while ensuring [their] safety and security'. (Note 31) Since its introduction by the Treaty of Amsterdam, this concept has been mentioned in various Union documents and it is now part of the Treaty on the Functioning of the European Union. (Note 32) Different EU policy areas are covered by this concept and, over time, different programmes, such as the recently adopted Stockholm Programme, (Note 33) have been designed to embody it. (Note 34)

Through the Stockholm Programme, the Council asked the EU Member States and the Commission to 'examine how to improve legislation and practical support measures for the protection of victims and to improve the implementation of existing instruments'. (Note 35) The establishment of an open and secure Europe as a priority for the Union as whole had contributed to the adoption of the Directive, which is larger in size and contains 
detailed rights entitled to victims of crimes. This detailed character of the Directive leaves little room for discretion and interpretation, as was the case with the Framework Decision. It is now to the Member States to implement the objectives of the Directive in order to achieve minimum harmonisation on the rights, support and protection of victims of crime.

\subsection{Conclusion}

Which developments and legal provisions preceded the final draft of the Directive must be established in light of the internationalised attention for the position of victims of crimes. From the 1980s onward, different soft law instruments have been adopted to ensure victims compensation. Although the content of these measures was quite similar, measures taken by the EU have had a binding character. The widely-interpretable obligations of the Framework Decision have been replaced by the Directive's detailed rules. This can certainly affect the by the EU desired minimum harmonisation of this matter on the European level.

\section{Protection of Child Victims Who Are Witnesses in Criminal Proceedings under the Directive}

\subsection{Introduction}

The Directive was adopted in light of the described developments with regard to victim protection in the EU, thereby replacing the Framework Decision on the standing of victims in criminal proceedings. The Directive recognises that European citizens falling victim to crime, especially those who are particularly vulnerable, such as children, should be able to rely on minimum standards recognised throughout the Union. (Note 36) At the same time, protecting the right to fair trial of the suspect cannot be disregarded. This chapter examines how the Directive protects child victims who are witnesses in criminal proceedings and how it takes into account the right to fair trial of suspects.

First, the rights of child victims who are witnesses as laid down in the Directive are discussed. Second, the status of the Directive provisions in national legal orders is examined. Where children can invoke the Directive provisions before national courts through direct effect, the threat to the right to fair trial of the suspect might be more immediate. Third, the interpretation of the ECJ of the scope of victim rights, including those of children, as recognised by the Framework Decision is analysed. Fourth, it is discussed how the Directive takes into account the right to fair trial of suspects and which provisions of the Directive may be incompatible with the right to fair trial.

\subsection{The Provisions of the Directive}

The Directive recognises that special victims may need specific protection. It states that Member States shall ensure that measures are available to protect victims from secondary victimisation, especially by protecting their dignity during questioning and when testifying. (Note 37) Child victims are likely to experience a high rate of secondary victimisation due to their vulnerability. (Note 38 ) Therefore, the Directive presumes that child victims need specific protection. (Note 39) Where the victim is a child, the child's best interests shall be a primary consideration and shall, moreover, be assessed on an individual basis. (Note 40)

It follows from these considerations that Member States are required to ensure that child victims who are witnesses in criminal proceedings receive an individual assessment to identify specific protection needs and to determine whether they would benefit from the special measures under Articles 23 and 24 of the Directive.

Article 23 sets out measures available to victims with specific protection needs during criminal proceedings. It is of note that the role of victims who are witnesses in criminal proceedings varies from state to state. (Note 41) Naturally, the measures appropriate to ensure the specific protection needs of the victim depend on the stage of the proceedings. For this reason, the Directive distinguishes between protective measures during criminal investigations in Article 23(2) (Note 42) and during court proceedings in Article 23 (3) (Note 43). Member States are expected to ensure that these protective measures are made available throughout criminal proceedings at the appropriate stages. (Note 44)

Article 24 provides for an additional set of available measures for child victims. With regard to child victims who are witnesses, Member States are obliged to guarantee that all interviews with the child victim may be audiovisually recorded and that such recorded interviews may be used as evidence in criminal proceedings. (Note 45) It is for the Member States to determine procedural rules for these recordings.

\subsection{Status of Directive Provisions in National Legal Orders}

The adoption of the Directive replaced the Framework Decision. The preamble of the Directive states its intention to amend and expand the provisions of the Framework Decision. (Note 46) This is an interesting observation, not only with regard to the scope of victim protection, but also with regard to the question whether individuals can rely on the provisions of the Directive before national courts. 
Since the Lisbon Treaty entered into force, the EU's regulating competences in criminal matters have increased in number. Under European Community law, criminal law was part of the Third Pillar and regulatory initiatives by the EU thus remained limited to adopting framework decisions. (Note 47) The ECJ assumed jurisdiction over these framework decisions only in relation to the obligation of Member States to interpret national law in light of these framework decisions. (Note 48) The Lisbon Treaty, however, provided the Union with the competence to adopt legal instruments of the former First Pillar in certain fields of criminal law in order to facilitate mutual recognition of judgments and judicial decisions and police and judicial cooperation in criminal matters with a cross-border dimension. With regard to the rights of victims, the Union is competent to establish minimum rules by means of directives. (Note 49)

As is well known, provisions of directives might have direct effect, meaning that individuals can invoke them before national courts. Since it was not possible for victims to invoke the provisions of the Framework Decision, it is interesting to analyse whether this is the case for the provisions of the Directive. As famously stated by the ECJ, provisions of Directives may have direct effect:

'[W]herever the provisions of a directive appear, as far as their subject-matter is concerned, to be unconditional and sufficiently precise, those provisions may (...) be relied upon as against any national provision which is incompatible with the directive or in so far as the provisions define rights which individuals are able to assert against the State.' (Note 50)

In principle, (Note 51) directive provisions can only have direct effect after the period for transposition into national law has expired. (Note 52) Whether a directive provision is sufficiently precise is determined by its wording. The unconditional character of a provision deals with the question whether implementation measures are still required for the provision to achieve its objectives. (Note 53)

Although the direct effect of provisions of the Directive might vary from case to case (Note 54), it should be noted that the preamble provides a strong indication of their possible applicability. Namely, it states that the Directive 'confers rights on victims of extra-territorial offences only in relation to criminal proceedings that take place in the Union.' (Note 55)

The wording of the provisions applicable to the protection of child victims who are witnesses confirms the specific nature of the rights laid down in the Directive. This notion is confirmed when compared to the wording of the Framework Decision, which requires Member States, rather inexplicitly, to ensure that vulnerable victims are entitled to testify in a manner which protects victims from the effects of giving testimony in open court. (Note 56)

For example, Article 24 states that Member States have to ensure that where the victim is a child all interviews may be recorded and may be used as evidence. It seems probable to assume that a child who has been summoned to testify in court may directly rely on its right to be audiovisually recorded outside the court. Resultantly, this might affect the right to fair trial of the suspect in cases where national authorities previously had discretion to determine in which way testimony of the child victim had to be taken.

\subsection{The European Court of Justice on Victim Rights}

As stated above, its preamble specifically states that the Directive means to amend and expand the provisions of the Framework Decision. (Note 57) Therefore, it is interesting to analyse ECJ case law relating to the Framework Decision as it gives a clear image of its stance towards victim rights, particularly concerning child victims who are witnesses.

Pupino is the first case in which a national court referred to the ECJ to give an interpretation of the Framework Decision. An Italian teacher was accused of maltreating a number of five-year-old children. The public prosecutor asked the referring court whether it could take the testimony of the child victims at the pre-trial stage in order to protect them from examination at the trial stage. Italian law provided this protection only to child victims in sexual abuse cases. The referring court, therefore, asked the ECJ whether, in light of the Framework Decision, this procedure should also be available for child victims of other crimes, such as maltreatment.

The ECJ stressed that child victims of maltreatment, given their age and the nature and consequences of the alleged offences, classify as particular vulnerable victims. (Note 58) These victims should thus be able 'to use a special procedure, (...), if that procedure best corresponds to the situation of those victims and is necessary in order to prevent the loss of evidence, to reduce the repetition of questioning to a minimum, and to prevent the damaging consequences, for those victims, of their giving testimony at the trial.' (Note 59)

However, the Framework Decision must be interpreted with respect for fundamental rights, including the right to fair trial as established in Article 6 ECHR. (Note 60) Therefore, it should be ensured that the proceedings as a whole remain fair for the suspect. (Note 61) More specifically, the ECJ ruled in the Katz case that Article 6(3)(d) 
ECHR, which ensures the right for the defendant to examine or have examined witnesses, also applies to the testimony of the victim. (Note 62)

As a general rule, the ECJ ruled that the Framework Decision requires the Member States to recognise that victims enjoy a high level of protection and have an appropriate role in the criminal legal system. (Note 63) Accordingly, its provisions imply that the victim should be able to give a testimony which can be used as evidence. (Note 64) However, the Framework Decision must be interpreted as leaving wide discretion to the national authorities as to how to achieve its objectives. Member States are not obliged to treat victims and suspects in an equivalent manner. (Note 65) In the $X$ case, the ECJ ruled that the Framework Decision does not preclude rules that do not impose an obligation on the national authorities to offer particularly vulnerable victims the possibility to be heard and give evidence under specific protective arrangements during criminal investigations. (Note 66)

\subsection{Right to Fair Trial of Suspects under the Directive}

It is clear that the Directive intends to offer strong protection to child victims who are witnesses in criminal proceedings. Notwithstanding the importance of such protection, the right to fair trial for the suspect should not be disregarded. The question that lies before us is how to balance the right to fair trial and child victim protection. Particularly, the provision which allows all recorded interviews to be used as evidence raises questions with regard to the right of the suspect to examine witnesses. This section analyses the relation between the rights of child victims who are witness and the rights to fair trial of suspects within the scope of the Directive.

The preamble clearly states that the rights set out in the Directive are without prejudice to the rights of the offender. The term 'offender' refers both to persons convicted and suspected of a crime. (Note 67) The extent of any measure protecting specific needs of victims should be determined without prejudice to the rights of defence and in accordance with the rules of judicial discretion. (Note 68)

In order to determine what the right to fair trial entails in the context of the Directive, the Charter of Fundamental Rights of the European Union is of significant importance. According to its preamble the Directive shall respect all fundamental rights and principles recognised in the Charter, including the right to a fair trial, the rights of the child, and the right to dignity. (Note 69) The specific features of the Charter are discussed in the next Chapter.

It is difficult to deduce from these general observations in the Directive how far the right to fair trial reaches where the victim is a child. Nevertheless, the interpretation of the ECJ of the Framework Decisions in cases such as Pupino may provide guidelines. These judgments have been interpreted in the literature as recognising that the right to fair trial prevails over victim protection. (Note 70) The ECJ recognised a wide discretion for national authorities in deciding to apply protective measures as long as the national legal systems provided for the possibility of adopting specific protective measures for victims. (Note 71) The ECJ held with so many words that protective measures for victims must be designed in such a way that the right to fair trial is respected. (Note 72)

More specifically, this primacy of fair trial means that real-time video conferencing is the preferable method to balance the protection of the witness and the right to examine the witness. (Note 73) Video recording the interviews may be an alternative provided that the inability for the suspect to examine the victim as a witness is sufficiently counterbalanced with safeguards in favour of the suspect. (Note 74) In contrast, Article 24 of the Directive states that where the victim is a child interviews may be audio-recorded and be used as evidence. (Note 75) Considering this wording, it is at least questionable whether or not this provision requires counterbalancing factors. Therefore, its compatibility with the right to fair trial may be questioned, especially given the possibility that children might be able to rely on Article 24 directly before a national court

\subsection{Conclusion}

It can be concluded that the Directive intends to provide extensive protection to child victims who are witnesses in criminal proceedings. The scope of the Directive is considerably wider than that of the Framework Decision, especially considering the possible direct effect of its provisions. It appears that the rights of child victims who are witnesses as laid down in the Directive have been expanded significantly compared to the ECJ's interpretation of the Framework Decision provisions. The rights of child victims are, however, without prejudice to the rights of the suspect. Specifically, it is questionable whether Article 24 is ultimately compatible with the right to fair trial. To further investigate this notion, it is necessary to examine its compatibility with the right to fair trial as laid down in the Charter of Fundamental Rights of the European Union and the European Convention on Human Rights. 


\section{The Directive in Light of the Charter of Fundamental Rights of the European Union}

\subsection{Introduction}

Although initially fundamental rights were not included in the institutional nature of the predecessors of the EU, its institutions developed these rights over time. (Note 76) The ECJ contributed actively in shaping and granting such fundamental rights, (Note 77) while it once ruled that it cannot assess community law in light of national fundamental rights. (Note 78) For this reason, it was said that the ECJ 'excluded fundamental rights from the legal order of the [European Economic Community]'. (Note 79) Approximately ten years after this ruling, the ECJ decided that 'fundamental human rights enshrined in the general principles of community law and protected by the court'. (Note 80) This was a confirmation for the institutions of the EU to consider fundamental rights as the basis for their own functioning. (Note 81) In 1970, the ECJ stated that 'the protection of such rights, whilst inspired by the constitutional traditions common to the member states, must be ensured within the framework of the structure and objectives of the community'. (Note 82) The ECJ continued this line and added in 1974 international treaties, first and foremost the ECHR, to its sources of inspiration in shaping general principles of Community law. (Note 83) Critics stated that this implied 'evoking the idea of a common European tradition in the respect of human rights', without carrying out proper comparative studies on the nature of the constitutions of the Member States that may support this point of view. (Note 84)

From the mid-1980s onward, fundamental rights were considered the foundation grounds of the EU by its institutions, which opened a debate on the codification of these rights. (Note 85) Resultantly, fundamental rights were adopted in several Union documents as the foundation grounds of the Union. (Note 86)

The Charter of Fundamental Rights of the European Union (hereafter 'the Charter') was adopted in December 2000 by the European Parliament, the European Council, and Commission in order to establish 'citizenship of the Union' and to create an area of freedom, security and justice. This was the immediate result of the decision taken by the European Council to introduce a 'Charter of Fundamental Rights of the European Union'. (Note 87) Different reasons were given for the establishment of such a non-binding European document granting fundamental rights to its citizens. (Note 88) The Preamble of the Charter states that strengthening the protection of fundamental rights was necessary 'in light of changes in society, social progress and scientific and technological developments'. The Charter also said that codifying the fundamental rights was a 'reaffirmation' of the rights derived from the ECHR and the rights granted to individuals by the European Court of Human Rights'. (Note 89) The Charter contains different traditional civil and political freedoms, social rights, and general provisions. (Note 90) The protection of these human rights at the Union level became more 'significant' after the entry into force of the Treaty of Lisbon. By then, the Charter was legally binding and, as a result, human rights became part of the Union's primary law. (Note 91) Thus, the Charter had a triple function. First, as a principle of Union law, the Charter can be used as a tool for interpretation. Second, this document can serve as ground for judicial review. Third, this Charter can provide inspiration to shape and establish general principles. (Note 92)

For the scope of this study it is of importance to assess whether the Directive, with its specific provisions concerning the protection of child victims, as laid down in section 24 of the Directive, is compatible with the Charter.

\subsection{The Compatibility of the Directive with the Charter}

As said before, the Charter offers equal or higher standards of protection than the ECHR. (Note 93) This means that the level of protection may never be under the level of protection provided by the ECtHR. (Note 94) For this reason it is of importance to determine to what extent the right to fair trial and the rights of defence, as laid down in the Charter, are guaranteed by this Directive. (Note 95) We limit ourselves to these two rights as they may be at stake by the implementation and application of Section 24 of the Directive.

Considering the rights that are also secured by the ECHR, the Charter notes in Section 52, paragraph 3, that the scope and the meaning of these rights 'shall be the same as those laid down by the [ECHR]'. What does this means for Section 47 and 48 of the Charter, which codified the right to an effective remedy and to fair trial, and the presumption of innocence and the right of defence?

The second paragraph of Section 47 states that '[e]veryone is entitled to a fair and public hearing within a reasonable time by an independent and impartial tribunal previously established by law. Everyone shall have the possibility of being advised, defended and represented'. The explanation of this right says that '[in] Union law, the right to a fair hearing is not confined to disputes relating to civil law rights and obligations'. That is one of the consequences of the fact that the Union is a community based on the rule of law as stated by the Court in the Les Verts case. (Note 96) 'Nevertheless, in all respects other than their scope, the guarantees afforded by the ECHR 
apply in a similar way to the Union'. (Note 97) Although several preliminary questions about the interpretation of Section 47 were asked in recent years, none of these questions show any relevance for the purpose of this study. (Note 98) The explanation of Section 48 is much shorter. This right 'has the same meaning and scope as the right guaranteed by the ECHR'. (Note 99)

In the only relevant case that exists in relation to Section 47, and then in particular concerning the 'fair trial' part of this Section, the ECJ had said that 'the right to a fair trial, which derives inter alia from Article 6 of the ECHR, constitutes a fundamental right which the EU respects as a general principle under Article 6(2) EU'. (Note 100) It appears from the case law of the ECJ that the fundamental rights that are offered in the ECHR have a 'special significance' in the legal order of the Union and are an integral part of the general principles of the Union. (Note 101) Maduro concluded in his opinion that the ECJ 'is required to take into account the case-law of the European Court of Human Rights when interpreting the fundamental rights'. (Note 102)

As a consequence of the reference, whether or not explicitly, that is made by the ECJ, the Charter itself and the Treaty on the European Union, to the case law of the ECHR, the question whether Section 24 of the Directive is compatible with the Charter, must be answered in light of the case law of the ECHR, taking into account the safeguards that thereby were provided.

\subsection{Conclusion}

Although fundamental rights received the status of primary Union law, the establishment of the Charter does not imply that the 'ECJ has become 'a second European Court on Human Rights',. (Note 103) The Charter provides a binding guideline for the Union institutions and Member States in the interpretation of the guaranteed rights. Interpreting these freedoms in light of the ECHR, as laid down in the Charter, is a codification of the ECJ settled case law. This means that the compatibility of the right to fair trial and the right of defence with the Directive must be assessed in light of the ECHR case law.

\section{Participation of Child Victims in Criminal Proceedings and Fair Trial under the European Convention on Human Rights}

\subsection{Introduction}

The Directive obliges states to allow audio-recorded testimonies by children as evidence in criminal cases. As stated before, this might contradict the right to fair trial, a right that has been recognised by a variety of legal documents. (Note 104) Citizens of Member States to the ECHR have direct access to the ECtHR and all EU Member States have ratified the ECHR. Thus, all people affected by the Directive can also rely on the ECHR. A subsequent violation of the right to fair trial as a result of the use of invalid evidence could therefore constitute for a discrepancy between ECHR case law and the Directive.

It is therefore paramount to investigate how the ECHR and ECtHR case law protect the right to fair trial in relation to the participation of child victims in criminal proceedings.

\subsection{Relevant Provisions of the European Convention}

\subsubsection{The Right to Fair Trial}

The right to fair trial is guaranteed under Article 6 of the European Convention and provides everyone with the right to a fair trial. (Note 105) This right includes several other rights, including the right to cross-examine witnesses, which is safeguarded under Article 6(3)(d). (Note 106) In principle, witnesses should thus attend a hearing in order to have their testimony considered in court.

\subsubsection{Victims' Rights to Participate in Criminal Proceedings}

The European Convention protects the rights of all people, including victims and witnesses, within its scope. For instance, it protects the right to life (Article 2), the right to private life (Article 8), and the freedom of expression (Article 10). These rights could be applicable to victims whose audio-recorded testimonies; however, the European Convention does not explicitly guarantee child victims' right to participate in criminal cases. (Note 107)

\subsection{Case Law of the European Court of Human Rights}

\subsubsection{Interests of the Suspect v. Interests of the Witness}

As stated before, the European Convention states that witnesses should be present at trial for them to be cross-examined by the defendant. While no exception is given in the Convention, ECtHR case law does provide exceptions to this rule. This was first recognised in the Doorson case. (Note 108) 
Hereafter, it also made clear that the ECtHR does recognise the interests of witnesses, but acknowledges that a deviation from Article 6 ECHR would create a handicap for the defence. Hence, it states, procedures taken by judicial authorities should, in this case, counterbalance the defence's handicap. (Note 109)

\subsubsection{Counterbalancing Factors}

The previous paragraph showed that the ECtHR does recognise the interests of witnesses. As this research focusses on child victims, this paragraph will outline the counterbalancing factors that give these child victims the opportunity to have their testimonies audio-recorded outside of the courtroom and used as evidence.

In P.S. v. Germany (Note 110), the defendant was accused of having sexually abused an eight-year-old girl. As the District Court believed that the girl might relive her trauma if questioned at trial, it relied solely on evidence obtained from a short police interview with the girl and a statement of the mother, to whom the girl had spoken to right after the incident. In appeal the Regional Court, however, believed that the District Court's reasons for declining the defendant's request for an expert opinion were too vague and, subsequently, hired an expert to assess the girl's reliability. (Note 111)

The ECtHR, nevertheless, found a violation of the defendant's right to fair trial as, first, there had been a delay of 18 months between the alleged event in question and the preparation of the opinion; second, the evidence provided by the girl was reported in court by third persons, and; third, the girl's testimony was the only evidence available. (Note 112)

In the S.N. case (Note 113) the defendant was accused by a ten-year-old boy, who testified twice to the police that he had been abused. The child was not examined in court; however, the counsel of the defendant was invited to both testimonies, of which the first was video-recorded and the second audio-recorded. The interviews with the child were conducted by a police officer with long-standing experience in child abuse cases and, while the counsel of the defendant had agreed not to be present at the interview, it did collaborate with the police in determining which aspects the interview would focus on. The counsel was also given opportunity to put questions to the child, but refrained from doing so. The interviews were shown during trial. (Note 114)

While the Court acknowledged that the defendant did not have the opportunity to exercise his rights fully, it believed that the high standards that are required to counterbalance the absence of a witness were met by the above-mentioned conditions. Hence, no violation of Article 6(3)(d) was established. (Note 115)

In contrast to S.N., the ECtHR did find a violation of the right to fair trial in the Bocos Cuesta case. (Note 116) In this case, four children had testified to the police that they had been sexually assaulted by the defendant, who was subsequently convicted. The defence's request to have the witnesses heard in court was denied by the Dutch Court of Appeals as it believed that the possible trauma the children would suffer weighed more heavily than the defendant's interest in hearing the children in court. The Court of Appeals found the testimonies reliable as they were highly similar, the witnesses had recognised the defendant, the police offers who questioned the children were highly experienced in child abuse cases and posed open-ended questions, and the testimonies were taken individually and corroborated each other. (Note 117)

The ECtHR disagreed with the Dutch Court of Appeal and found the proceedings unfair as the witness testimony was the only evidence in the case. Also, it was not firmly established that the children would relive trauma if faced with the defendant in court. Here, an expert opinion could have made a difference. Furthermore, the children's statements were not recorded on tape and, as a result, the judges were not able to observe the actual statements, but, rather, an interpretation of them. (Note 118) Resultantly, a violation of Article 6(3)(d) was established. (Note 119)

In contrast to Bocos Cuesta, the child victim's testimony in the A.L. case (Note 120) was recorded and shown in court, which allowed the defendant and the judge to, at least to some degree, assess the credibility of the child. The defendant was also allowed to give comments on the evidence against him. (Note 121) The ECtHR, however, stated that, because the counsel of the defendant had not been given the opportunity to pose questions to the witness a violation of Article 6(3)(d) ECHR had taken place. (Note 122) Another heavy-weighing factor was, in the Court's opinion, the fact that the testimony by the child constituted for the only direct evidence for the alleged sexual abuse by the defendant. (Note 123)

In Bykov v. Russia (Note 124), however, the ECtHR stated that unsupported evidence does not necessarily pose a threat to fairness: 'it may be noted that were the evidence is very strong and there is no risk of its being unreliable, the need for supporting evidence is correspondingly weaker.' (Note 125) This quote confirms that the Court counterbalances all factors in a specific case to determine whether a violation of the right to fair trial has taken place. 


\subsubsection{Sole or Decisive Rule}

The evidence in sexual abuse cases involving children is often limited and, in some occasions, the victim's testimony is the only significant evidence. In dealing with such evidence, the ECtHR created the so-called 'sole or decisive rule', which was stated in the Lucà judgement. (Note 126) This rule was maintained for over 10 years until Al-Khawaja \& Tahery v. United Kingdom. (Note 127) The claims by Mr Al-Khawaja and Mr Tahery were filed separately, but as they both dealt with whether the absence of a witness was satisfactorily counterbalanced and as they were both directed at the United Kingdom, they were dealt with jointly.

Mr Al-Khawaja was a British consultant physician who was accused by one of his patients, ST, of sexually assaulting her while she was under hypnosis. The accusation was brought a few months after the event had taken place. Another woman, VU, also reported that Mr Al-Khawaja had sexually assaulted her. Before the trial could take place, however, ST committed suicide, which left het unable to testify in court. The judge, as a result, decided to read her statement, which was recorded by the police, to the jury, but instructed to accord less weight to it as it was not possible to cross-examine the witness. Two of ST's friends, who she had confessed to after the event, and ST's general practitioner, who had written a letter to a hospital in which he described the allegation against $\mathrm{Mr}$ Al-Khawaja, were questioned in court. Mr Al-Khawaja was subsequently convicted and, also, the Court of Appeals did not establish a violation of the right to fair trial under Article 6 ECHR. (Note 128)

The ECtHR stated that, while the evidence by ST was decisive (Note 129), there had been sufficient counterbalancing factors to find no violation of the right to fair trial. (Note 130) In particular, it emphasised on the fact that 1) ST was unable to testify in court, 2) ST had told her friends of the event in question right after it had happened 3) ST's statement was properly recorded and could thus be assessed by the court, 4) there were only minor discrepancies between ST's statement and the accounts given by her two friends, and, most importantly, 5) ST's statement showed strong similarities with that of VU, with whom there was no proof of collusion. (Note 131)

Mr Tahery had gotten into a fight with another man, S, who, during the fight, was stabbed in the back with a knife. $\mathrm{S}$ could not say with certainty who stabbed him, but a witness, $\mathrm{T}$, told the police that he had seen Mr Tahery doing so. Out of fear of retribution, $T$ refused to testify in court, which the presiding judge found reasonable. After instructing the jury to give less weight to T's statement due to his absence, the judge allowed the statement as evidence. Resultantly, Mr Tahery was convicted without having the opportunity to cross-examine witnesses. (Note 132)

In contrast to Al-Khawaja, the ECtHR did find a violation of the right to fair trial in the Tahery case. (Note 133) It stated that T's statement was uncorroborated by other evidence and, thus, that it was the decisive, if not sole, evidence in establishing Mr Tahery's guilt. (Note 134) In this regard, in counterbalancing Mr Tahery's inability to examine witnesses, T's statement weighed heavily. The ECtHR found that the counterbalancing factors that were approved by the Court of Appeal, including Mr Tahery's ability to call on witnesses and challenge T's statement, were insufficient to counterbalance the sole evidence provided by T's statement and his absence in court. (Note 135)

The outcome of Al-Khawaja shows that the Court no longer enforces the 'sole or decisive rule' in an absolute manner. In fact, it restated the rule in such a way that the segment 'the rights of the defence are restricted' to a more lenient 'the rights of the defence may be restricted'. (Note 136)

\subsubsection{Model to Assess a Situation in Which a Witness Cannot Be Cross-examined}

In Al-Khawaja \& Tahery, the Court also drew up a decision-making model to determine whether a violation of the right to fair trial had occurred in situations where it was not able to cross-examine a witness. (Note 137)

The first question this model poses is whether it is necessary to admit the witness statement. This question can also be rephrased to whether there is a good reason for the non-attendance of a witness whose statement is used as evidence. The Court phrases this as follows:

'The requirement that there be a good reason for admitting the evidence of an absent witness is a preliminary question which must be examined before any consideration is given as to whether that evidence was sole or decisive. Even where the evidence of an absent witness has not been sole or decisive, the Court has still found a violation of Article $6 \S \S 1$ and 3(d) when no good reason has been shown for the failure to have the witness examined.' (Note 138)

From this quote, it can be deduced that this model does not only apply to 'sole or decisive' evidence. 
Secondly, it must be assessed whether the evidence that was not tested for reliability was the sole or decisive basis for conviction. As could be noticed from the way the ECtHR dealt with the evidence in Tahery, stronger counterbalancing forces are necessary in case of sole or decisive evidence.

Thirdly, the model asks whether there were there sufficient counterbalancing factors, including strong procedural safeguards, to ensure that the trial, judged as a whole, was fair?

\subsection{Conclusion}

The last question in the Al-Khawaja \& Tahery model clearly shows the development of the Court in dealing with the right to fair trial and witness participation of (child) victims. While previous ECtHR case law offered little clarity on its decision-making process in assessing whether a violation of the right to fair trial was caused by the absence of a witness, the current doctrine gives national courts more support in making this assessment themselves. The only question left is what factors tip the balance to the one side or the other. Here, the established case law can provide national courts with the weight of these factors.

\section{Conclusion}

An interesting observation is that the seemingly absolute right for child victims to participate in criminal proceedings through audio-recorded testimonies, as guaranteed by Article 24(1)(A) of the Directive, seems to be incompatible with the rights of suspects guaranteed under the ECHR and the Charter under most circumstances.

This incompatibility becomes problematic through the possible - and likely - direct effect of the Directive. This would create a situation in which a child victim may rely on the provisions in the Directive before a national court while the suspect can effectively call upon the right to fair trial before the ECtHR.

These findings raise the question of how EU Member States are supposed to implement the content of the Directive in national law without violating the right to fair trial, as guaranteed by both the ECHR and the EU Charter. The answer to this question can be found in ECHR case law, which contains the factors that can or cannot counterbalance a breach of the defendant's right to have witnesses examined in court. In implementing the Directive, Member States are thus advised to take all counterbalancing measures possible.

However, these implementation possibilities do not conceal the Directive's lack of regard of suspect rights. It offers a variety of rights to victims and even more to special victims, but it almost completely disregards one of the foundations of democracy: the right to fair trial. The EU Member States are obliged to implement the content of the Directive to national law by 16 November 2015. (Note 139) However, the European Commission could have made this process a lot easier by considering suspect rights as well. If the latter were the case, perhaps the summum ius it aims to guarantee would not lead to a possible summa iniuria.

\section{References}

Bassiouni, M. C. (2006). International Recognition of Victims' Rights. Human Rights Law Review, 6, 203-279. http://dx.doi.org/10.1093/hrlr/ngl009

Beijer, A., \& Liefaard, T. (2011). A Bermuda Triangle? Balancing Protection, Participation and Proof in Criminal Proceedings Affecting Child Victims and Witnesses. Utrecht Law Review, 7(3), 70-106.

De Wilde, B. (2012). A fundamental review of the ECtHR right to examine witnesses in criminal cases. (Unpressed).

Douglas-Scott, S. (2011). The European Union and Human Rights after the Treaty of Lisbon. Human Rights Law Review, 11, 645-682. http://dx.doi.org/10.1093/hrlr/ngr038

Fernández De Casadevante Romani, C. (2010). International Law of Victims. Max Planck Yearbook of United Nations Law, 14, 219-272.

García, R. A. (2002). The general provisions of the Charter of Fundamental Rights of the European Union. European Law Journal, 8, 492-514. http://dx.doi.org/10.1111/1468-0386.00162

Groenhuijsen, M. S., \& Pemberton, A. (2009). The EU Framework Decision for Victims of Crime: Does Hard Law Make a Difference? European Journal of Crime, Criminal Law and Criminal Justice, 17, 43-59. http://dx.doi.org/10.1163/157181709X400386

Herlin-Karnell, E. (2008). The Lisbon Treaty and the Area of Criminal Law and Justice. European Policy Analysis, 3, 1-10.

Katsoris, N. C. (1990). The European Convention on the Compensation of Victims of Violent Crimes: A Decade of Frustration. Fordham International Law Journal, 14, 186-215. 
Koen, L. (2012). Exploring the Limits of the EU Charter of Fundamental Rights. European Constitutional Law Review, 8, 375-403. http://dx.doi.org/10.1017/S1574019612000260

Lenaerts, K. (2012). Exploring the Limits of the EU Charter of Fundamental Rights. European Constitutional Law Review, 8(3), 375-403. http://dx.doi.org/10.1017/S1574019612000260

Luchtman, M. (2012). Principles of European Criminal Law: Jurisdiction, Choice of Forum, and the Legality Principle in the Area of Freedom, Security, and Justice. European Review of Private Law, 2, 347-380.

McCrudden, C. (2002). The Future of the EU Charter of Fundamental Rights. Working paper series. Retrieved from http://papers.ssrn.com/sol3/papers.cfm?abstract_id=299639 (accessed 29 January 2013).

McEwan, J. (2009). The testimony of vulnerable victims and witnesses in criminal proceedings in the European Union. ERA-Forum, 10(3), 369-386. http://dx.doi.org/10.1007/s12027-009-0126-3

Schünemann, B. (2009). Protection of children and other vulnerable victims against secondary victimisation: making it easier to testify in Court. ERA-Forum, 10(3), 387-396. http://dx.doi.org/10.1007/s12027-009-0130-7

Sebba, L. (1982). The Victim's Role in the Penal Process: A Theoretical Orientation. American Journal of Comparative Law, 30(2), 217-240. http://dx.doi.org/10.2307/839627

Smismans, S. (2010). The European Union's Fundamental Rights Myth. Journal of Common Market Studies, 48, 45-66. http://dx.doi.org/10.1111/j.1468-5965.2009.02041.x

Verhoeven, M. J. M. (2011). The Costanzo obligation: the obligations of national administrative authorities in the case of incompatibility between national law and European law. Cambridge: Intersentia.

Vervaele, J. A. E. (2005). European Criminal Law and General Principles of Union Law. In J. A. E. Vervaele (Ed.), European Evidence Warrant. Transnational Judicial Inquiries in the EU. Antwerpen - Oxford: Intersentia.

Vogel, J. (2005). The European integrated criminal justice system and its constitutional framework. Maastricht Journal of European and Comparative Law, 12, 125-148.

Willis, B. L. (1984-1985). State Compensation of Victims of Violent Crimes: The Council of Europe Convention of 1983. Virginia Journal of International Law, 25, 211-248.

\section{Case law}

ECJ 4 February 1959, Case C 1-58 (Stork).

ECJ 12 November 1969, Case C-29/69 (Stauder).

ECJ 17 December 1970, Case C-11/70 (Internationale Handelsgesellschaft).

ECJ 14 May 1974, Case C-4/73 (Nold).

ECJ 19 January 1982, Case C-8/81 (Becker).

ECJ 18 June 1991, Case C-260/89 (Elliniki Radiophonia Tiléorasi Anonimi Etairia).

ECJ 18 December 1997, Case 129/96 (Inter-Environnement Wallonie).

ECJ 6 March 2001, Case C-274/99 P (Connolly).

ECJ 22 October 2002, Case C-94/00 (Roquette Frères).

ECJ 12 June 2003, Case C-112/00 (Schmidberger).

ECJ 9 October 2008, Case C-404/07 (Katz).

ECJ 15 December 2011, Joined Cases C-483/08 and C-1/10 (Guaye and Salmeron Sanchez).

ECJ 21 December 2011, Case C-507/10 (X).

ECJ 16 June 2005, Case C-105/03 (Pupino).

ECJ 14 December 2006, Case C-305/05 (Ordre des barreaux francophones et germanophones).

ECJ 22 December 2010, Case C-279/09 (DEB). 
Opinion of Advocate General Poiares Maduro, Case C-305/05 (Ordre des barreaux francophones et germanophones and Others).

Preliminary questions, Case C-108/10 (Ivana Scattolon v Ministero dell'Università e della Ricerca).

ECtHR 26 March 1996, appl.no. 20524/92 (Doorson/the Netherlands)

ECtHR 27 January 2001, appl.no.23220/04 (A.L./Finland)

ECtHR 27 February 2001, appl.no. 33354/96 (Lucà/Italy)

ECtHR 20 December 2001, appl.no. 33900/96 (P.S./Germany)

ECtHR 10 November 2005, appl.no. 54789/00 (Bocos Cuesta/the Netherlands)

ECtHR 18 April 2006, appl.no. 37492/02 (Kovač/Hungary)

ECtHR 2 July 2007, appl.no. 34209/96 (S.N./Sweden)

ECtHR 10 March 2009, appl.no. 4378/02 (Bykov/Russia)

ECtHR 15 December 2011, appl.nos. 26766/05 \& 22228/06 (Al-Khawaja \& Tahery/United Kingdom)

\section{Legislation}

Council of Europe, European Convention for the Protection of Human Rights and Fundamental Freedoms, as amended by Protocols Nos. 11 and 14, 4 November 1950, ETS 5, available at: http://www.unhcr.org/refworld/docid/3ae6b3b04.html [accessed 23 January 2013].

Council of Europe, European Convention on the Compensation of Victims of Violent Crimes, 24 November 1983, CETS No. 116, available at: http://conventions.coe.int/Treaty/Commun/QueVoulezVous.asp?NT=116\&CM=8\&CL=ENG [accessed 23 January 2013].

European Union, Treaty on European Union (Consolidated Version), Treaty of Maastricht, 7 February 1992, Official Journal of the European Communities C 325/5; 24 December 2002, available at: http://www.unhcr.org/refworld/docid/3ae6b39218.html [accessed 29 January 2013]

European Union, Charter of Fundamental Rights of the European Union, 7 December 2000, Official Journal of the European Communities, 18 December 2000 (OJ C 364/01) available at: http://www.unhcr.org/refworld/docid/3ae6b3b70.html [accessed 23 Janaury 2013].

European Union, Consolidated version of the Treaty on the Functioning of the European Union, 13 December 2007, 2008/C-115/01, available at: http://www.unhcr.org/refworld/docid/4b17a07e2.html [accessed 23 January 2013].

European Council, Framework Decision 2001/220/JHA, 15 March 2001, Official Journal of the European Union, L $82 / 1$.

European Council, Framework Decision 2002/629/JHA, 19 July 2002, Official Journal of the European Union, L $203 / 1$.

European Council, Framework Decision 2004/68/JHA, 22 December 2003, Official Journal of the European Union, L 13/44.

European Council, Directive 2012/29/EU, 25 October 2012, Official Journal of the European Union, L 315/57.

\section{Other}

Committee of Ministers of the Council of Europe, Recommendation No. R (83) 7, 23 June 1983, recommendation on participation of the public in crime policy.

Committee of Ministers of the Council of Europe, Recommendation No. R (85) 11, 28 June 1985, recommendation on the position of the victim in the framework of criminal law and procedure.

Committee of Ministers of the Council of Europe, Recommendation No. R (87) 21, 17 September 1987, recommendation on assistance to victims and the prevention of victimisation. 
Committee of Ministers of the Council of Europe, Recommendation (2006) 8, 14 June 2006, recommendation on assistance to crime victims.

United Nations General Assembly, Resolution 77 (27), 28 September 1977, resolution on the Compensation of Victims of Crime.

United Nations General Assembly, The Stockholm programme - an open and secure Europe serving and protecting citizens, 4 May 2010, C115/1.

United Nations General Assembly, Resolution A/RES/40/34, 29 November 1985, Declaration of basic principles of justice for victims of crime and abuse of power

United Nations General Assembly, Resolution A/RES/47/133, 18 December 1992, Declaration on the protection of all persons from enforced disappearance

United Nations General Assembly, Resolution A/RES/60/147, 16 December 2005, Basic principles and guidelines on the right to a remedy and reparation for victims of gross violations of international human rights law and serious violations of international humanitarian law

United Nations General Assembly, Resolution A/RES/61/177, 20 December 2006, International Convention for the protection of all persons from enforced disappearance.

European Commission, Report from the Commission on the basis of Article 18 of the Council Framework Decision of 15 March 2001, 16 February 2004, COM (2004) 54 final/2.

European Commission, Report from the Commission on the basis of Article 18 of the Council Framework Decision of 15 March 2001, 20 April 2009, COM (2009) 166 final.

European Commission, Explanatory Memorandum Commission Proposal Directive 2011/0129 (COD)

Explanations relating to the Charter of Fundamental Rights, 14 December 2007, (2007/C 303/02)

Tweede Kamer der Staten-Generaal, Kamerstukken II 2001/02, 27 213, nr. 5, p. 1.

Joint Declaration by the European Parliament, the Council and the Commission concerning the protection of fundamental rights and the ECHR, 27 April 1977, OJ C103.

\section{Notes}

Note 1. Directive 2012/29EU (2012), Art. 24(1)(a).

Note 2. Sebba, L. (1982), at 217.

Note 3. Bassiouni, M. C. (2006), at 208. Bassiouni states that 'International law's concern for the protection of the individual is in part a result of legal developments that occurred in the wake of the atrocities of WWII and the international community's subsequent pursuit of individual criminal responsibility. Once international law made individuals subjects of that discipline for the purposes of international criminal responsibility, the individual became the subject of international legal rights, which explains, in part, the beginning of international human rights law. Until WWII, the rights and obligations of the individual vis à vis the State were the exclusive prerogative of municipal law, and a State was free under international law to treat its own citizens as it pleased. The magnitude of human victimisation arising out of WWI and WWII and the conflicts thereafter derived essentially from State action, either intentional or negligent. This new reality brought to the fore the need to extend the same rights and obligations that existed among the individuals within a society to the relationship between the individual victim and his/her victimiser. After WWII, numerous international instruments established protections and rights for individuals, requiring States to enact domestic legislation to protect these rights.'

Note 4. Willis, B. L. (1985), at 211.

Note 5. Fernandez De Casadevante Romani, C. (2010), at 222-228.

Note 6. UN GA, Resolution A/RES/40/34, 29 November 1985, Declaration of basic principles of justice for victims of crime and abuse of power. 
Note 7. UN GA, Resolution A/RES/47/133, 18 December 1992, Declaration on the protection of all persons from enforced disappearance; Resolution A/RES/60/147, 16 December 2005, Basic principles and guidelines on the right to a remedy and reparation for victims of gross violations of international human rights law and serious violations of international humanitarian law; Resolution A/RES/61/177, 20 December 2006, International Convention for the protection of all persons from enforced disappearance.

Note 8. The Inter-American Convention on Forced Disappearance of Persons is mentioned as an American norm that deals with victims' rights.

Note 9. Luchtman, M. (2012), at 348.

Note 10. Katsoris, N. C. (1990), at 186; UN GA, Resolution 77 (27), 28 September 1977, resolution on the Compensation of Victims of Crime.

Note 11. European Convention on the Compensation of Victims of Violent Crimes (1983), European Treaty Series - No. 116.

Note 12. Fernandez De Casadevante Romani, C. (2010), at 232.

Note 13. Willis, B. L. (1985), at 212.

Note 14. Katsoris, N. C. (1990), at 188.

Note 15. Willis, B. L. (1985), at 233.

Note 16. Committee of Ministers of the CoE, Recommendation No. R (83) 7, 23 June 1983, recommendation on participation of the public in crime policy. The recommendation entails in part $\mathrm{D}$ different proposals in order to establish 'a crime policy taking account of the victims' interests'.

Note 17. Committee of Ministers of the CoE, Recommendation No. R (85) 11, 28 June 1985, recommendation on the position of the victim in the framework of criminal law and procedure.

Note 18. Fernandez De Casadevante Romani, C. (2010), at 229.

Note 19. McEwen, J. (2009), at 370. It should be noted that the Council of Europe recommended in 1985 to take special measures related to procedures of questioning children. In 1987 the Council of Europe recommended to create special support service for victims with special need, such as child victims. See also the European Commission's Framework Decision 2004/68/JHA, 22 December 2003, on combating the sexual exploitation of children and child pornography; Framework Decision 2002/629/JHA, 19 July 2002, on combating trafficking in human beings.

Note 20. Committee of Ministers of the CoE, Recommendation No. R (85) 11, 28 June 1985, recommendation on the position of the victim in the framework of criminal law and procedure. The Council of Europe had developed several guidelines at police level, at the level of prosecution, court proceeding and the enforcement stage.

Note 21. Committee of Ministers of the CoE, Recommendation No. R (87) 21, 17 September 1987, recommendation on assistance to victims and the prevention of victimisation.

Note 22. Committee of Ministers of the CoE, Recommendation (2006) 8, 14 June 2006, recommendation on assistance to crime victims. Victims means according to the appendix of this recommendation, 'a natural person who has suffered harm, including physical or mental injury, emotional suffering or economic loss, caused by acts or omissions that are in violation of the criminal law of a member state. The term victim also includes, where appropriate, the immediate family or dependants of the direct victim.' 
Note 23. Council Framework Decision (2001/220/JHA), 15 March 2001, On the standing of victims in criminal proceedings ('Framework Decision'); Council Directive (2004/80/EC), 29 April 2004, Relating to compensation to crime victims.

Note 24. Framework Decision, Art. 17; Council Directive (2004/80/EC), Art. 18.

Note 25. Groenhuijsen, M. S. \& Pemberton A., (2009), at 43-47.

Note 26. Groenhuijsen, M. S. \& Pemberton A., (2009), at 47.

Note 27. Kamerstukken II 2001/02, 27 213, nr. 5, p. 1. The position of the Netherlands does not much differ from the attitude of other Member States. The Dutch Minister of Justice informs the Members of the House of Representatives that the government satisfied informed the Commission about its obligations as laid down in the Directive. The Minister states in this letter: 'De Regering trekt in deze brief de conclusie dat ons land aan de verplichtingen van het kaderbesluit voldoet. Die conclusie ligt in de lijn van de uitkomsten van het onderzoek naar de stand van zaken in tweeëntwintig landen in Europa, waarbij ons land wat betreft de praktijk als beste uit de bus kwam'.

Note 28. Report from the Commission on the basis of Article 18 of the Council Framework Decision of 15 March 2001, 16 February 2004, $\operatorname{COM}(2004) 54$ final/2. This Report states that 'no Member State can claim to have transposed all the obligations arising from the Framework Decision'.

Note 29. Report from the Commission on the basis of Article 18 of the Council Framework Decision of 15 March 2001, 20 April 2009, $\operatorname{COM(2009)} 166$ final. The Commission claims in this Report that 'no Member State transposed the Framework Decision in a single piece of national legislation. Member States all relied on existing provisions and many referred to their Code of Criminal Procedure for transposal. A few adopted new legislation covering one or more Articles. Many Member States submitted non-binding codes, Instructions and charters in lieu of legislation.'

Note 30. Groenhuijsen, M. S. \& Pemberton A., at 50.

Note 31. The First consideration of Directive 2012/29/EU: 'The Union has set itself the objective of maintaining and developing an area of freedom, security and justice, the cornerstone of which is the mutual recognition of judicial decisions in civil and criminal matters'.

Note 32. Title V of the Treaty on the Functioning of the European Union regulates the Area of Freedom, Security and Justice. It should be noted that this concept is also mentioned in the Charter of Fundamental Rights of the European Union and the Treaty on European Union.

Note 33. The Stockholm programme - an open and secure Europe serving and protecting citizens, 4 May 2010, C115/1.

Note 34. Vogel, J. (2005), at 128.

Note 35. The Stockholm programme - an open and secure Europe serving and protecting citizens, 4 May 2010, C115/1, at 10 .

Note 36. Explanatory Memorandum Commission Proposal Directive 2011/0129 (COD), p. 11.

Note 37. Directive 2012/29/EU, Art. 18.

Note 38. Preamble Directive 2012/29/EU, Art. 57.

Note 39. Directive 2012/29/EU, Art. 22(4).

Note 40. Directive 2012/29/EU, Art. 1. 
Note 41. Preamble Directive 2012/29/EU, Art. 20.

Note 42. E.g., Art. 23(2)(a) states that interviews with the victim may be carried out in premises designed or adapted for that purpose.

Note 43. E.g., Art. 23(3)(a) states that measures should be made available, including during the giving of evidence, to avoid visual contact between victims and offenders by appropriate means including the use of communication technology.

Note 44. Explanatory Memorandum Commission Proposal Directive 2011/0129 (COD), p. 10.

Note 45. Directive 2012/29/EU, Art. 24 (1) (a).

Note 46. Preamble Directive 2012/29/EU, Art. 65.

Note 47. Herlin-Karnell, E. (2008), at 2.

Note 48. Pupino (2005), para. 43.

Note 49. Art. 82(2) TFEU.

Note 50. Becker (1982), para. 25.

Note 51. Inter-Environnement Wallonie (1997) is an exception.

Note 52. Verhoeven, M. J. M. (2011), at 24.

Note 53. Verhoeven, M. J. M. (2011), at 22.

Note 54. Verhoeven, M. J. M. (2011), at 22.

Note 55. Preamble Directive 2012/29/EU, para. 13 [emphasis added].

Note 56. Framework Decision, Art. 8(4).

Note 57. Preamble Directive 2012/29/EU, Art. 65.

Note 58. Pupino, para. 53.

Note 59. Pupino, para 56.

Note 60. Pupino, para. 59.

Note 61. Pupino, para. 60.

Note 62. Katz (2008), para. 45.

Note 63. Katz, para. 46. 'Member States, first to ensure that victims enjoy a high level of protection and have a real and appropriate role in their criminal legal system and, second, to recognise victims' rights and legitimate interests and ensure that they can be heard and supply evidence.'

Note 64. Katz, para. 47; Gueye and Salmeron Sanchez (2011), para. 58.

Note 65. Gueye and Salmeron Sanchez, para. 53.

Note 66. $X$ (2011), para. 44. 'In the light of all the foregoing, the answer to the questions referred is that Articles 2, 3 and 8(4) of the Framework Decision must be interpreted as not precluding provisions of national law, such as Articles 392(1a), 398(5a) and 394 of the CPP, which, first, do not impose on the Public Prosecutor any obligation to apply to the competent court so that a victim who is particularly vulnerable may be heard and give evidence under the arrangements of the incidente probatorio during the investigation phase of criminal proceedings and, second, do not give to that victim the right to bring an appeal before a court against that decision of the Public Prosecutor rejecting his or her request to be heard and to give evidence under those arrangements.' 
Note 67. Preamble Directive 2012/29/EU, Art. 12.

Note 68. Preamble Directive 2012/29/EU, Art. 58, Directive 2012/29/EU, Art. 23(1).

Note 69. Preamble Directive 2012/29/EU, Art. 12.

Note 70. Schünemann, B. (2009), at 394; Beijer, A. \& Liefaard, T. (2011), at 98-9.

Note 71. Pupino, para. 44.

Note 72. Pupino, para.59; Katz, paras. 44-5.

Note 73. Schünemann, B. (2009), at 394.

Note 74. Schünemann, B. (2009), at 395. Schünemann states that the defendant and his defence counsel should be able to participate in such examination. In his opinion this safeguard is sufficient provided that the defence counsel must have had complete access to the records at that time and the prior examination must have been exhaustive.

Note 75. Apart from the question how the fair trial may be balanced with the rights of child victims, it is doubtful whether recorded evidence should be admissible as evidence. As stated in the literature, 'a potential barrier to the use of the [recorded] interview is that some recordings are unacceptable in terms of their technical quality or other visibility issues.' See McEwen, J. (2009), at 380.

Note 76. Smismans, S. (2010), at 46. Smismans writes that 'the original EEC Treaty did not include any reference to fundamental rights. Like the Council of Europe, the European Community were based on the ancestral myth that European integration was needed to ensure peace and avoid repetition of the terrible experiences of the two world wars. Yet, while the Council of Europe placed fundamental rights centre-stage, in particular through the adoption of the ECHR in 1950, for the EEC integration was economic and functional, without a constitutionalising process including fundamental rights. Contrary to the requirements for membership in the Council of Europe, respect for fundamental rights was not explicitly set as a condition to join the EEC. This omission was not accidental but the result of a deliberate choice.

Note 77. Vervaele, J. A. E. (2005), at 131. Vervaele says that the shaped principles by the ECJ 'are not so much general legal principles of an institutional character, such as the priority of Community law, direct effect or Community loyalty, but rather principles of law which shape the fundamental rights and basic rights of the citizen. I refer to the principle of legality, of nulla poena, the inviolability of the home, the nemo tenetur principle, due process, the rights of the defence, etc'. See also Douglas-Scott, S. (2011), at 648. 'Given the absence of any EU Bill of Rights until 2000, protection of fundamental rights for the first 40 years of European integration developed through the case law of CJEU'.

Note 78. Stork (1959), para. 4.

Note 79. McEwen, J. (2009), at 47.

Note 80. Stauder (1969), para. 7.

Note 81. García, R. A. (2002), at 493.

Note 82. Internationale Handelsgesellschaft (1970), para. 4.

Note 83. Nold (1974), para. 13.

Note 84. McEwen, J. (2009), at 48.

Note 85. See, for instance, the Joint Declaration by the European Parliament, the Council and the Commission concerning the protection of fundamental rights and the ECHR, 27 April 1977, OJ C103. 
Note 86. Smismans, S. (2010), at 49. The author refers to the Treaty of Maastricht. At that time, fundamental rights were for the first time set out in the Treaty foundation grounds of the European Union.

Note 87. See Annex IV, Conclusions of the European Council in Cologne, June 1999.

Note 88. McCrudden, C. (2002), at 8. McCrudden argues that 'the Charter could address the expansion of the Community to encompass the former Communist central and eastern European states where human rights were seen to need underpinning. The Charter could address the perceived need to secure the greater effectiveness of existing measures in the social rights field. (...) The fear in some quarters that the ECHR institutions might prove unable to handle the effective implementation of human rights in Eastern Europe and might become weakened more generally as a result meant that the Community should have its own Charter of Rights and not be dependent on the ECHR. The ECHR was, in any event, somewhat out-dated and in need of a revamping which would be impossible within the Council of Europe, given its decision-making structure. [Furthermore, a] Charter of Rights could deal with the apparent inconsistency of different human rights standards across the three Pillars of the Union.'

Note 89. Preamble of the Charter of Fundamental Rights of the European Union (2000/C 364/01).

Note 90. See also the Explanations relating to the Charter of Fundamental Rights, 14 December 2007, (2007/C $303 / 02$ ). It should be stressed that these explanations do not have the status of law; rather they could be serve as a source for interpretation. This also appears from the case law of the ECJ; see, for instance, DEB (2010), para. 32.

Note 91. Douglas-Scott, S. (2011), at 645. In the abstract of this article the author summarises the changes after coming into force of the Treaty of Lisbon. Douglas-Scott states that 'the Lisbon Treaty introduced significant changes to human rights protection in the EU, the most significant of which lie in the amendments to Article 6 of the Treaty on European Union. These provide that the EU Charter (...) is now legally binding, having the same status as primary EU law, and that the EU 'shall accede' to the [ECHR]'. No closing apostrophe, hence I don't know where the quote ends.

Note 92. Lenaerts, K. (2012), at 376. He refers to case law of the ECJ, in particular to ECJ, 23 December 2009, Case C-403/09 PPU (Detiček), para. 53.

Note 93. Art. 52(3) EU Charter. The meaning of this provision is explained as follows (see supra note 90): 'paragraph 3 is intended to ensure the necessary consistency between the Charter and the ECHR by establishing the rule that, in so far as the rights in the present Charter also correspond to rights guaranteed by the ECHR, the meaning and scope of those rights, including authorised limitations, are the same as those laid down by the ECHR. This means in particular that the legislator, in laying down limitations to those rights, must comply with the same standards as are fixed by the detailed limitation arrangements laid down in the ECHR, which are thus made applicable for the rights covered by this paragraph, without thereby adversely affecting the autonomy of Union law and of that of the Court of Justice of the European Union.'

Note 94. See supra note 92, at 394.

Note 95 . See Section 47 and 48 of the Charter.

Note 96. Les Verts v. European Parliament (1986). See also Explanations relating to the Charter of Fundamental Rights, on section 47.

Note 97. Explanations relating to the Charter of Fundamental Rights, on section 47.

Note 98. See, for instance, Ivana Scattolon v Ministero dell'Università e della Ricerca (2010): 'Must the (...) the right to an independent tribunal and, more generally, to a fair hearing, (...) be interpreted as precluding the 
adoption by the Italian State, after a significant period of time (5 years), of a specific interpretative provision which is at variance with the wording to be interpreted and in conflict with the consistent and settled interpretation of the institution responsible for ensuring uniform interpretation of the law [the Corte di cassazione], a provision which, moreover, is relevant for the purpose of resolving disputes to which the Italian State is a party?'. The other twelve preliminary procedures contain questions that are not relevant for the scope of this essay.

Note 99. Explanations relating to the Charter of Fundamental Rights, on section 48.

Note 100. Ordre des barreaux francophones et germanophones and Others (2006), para. 29.

Note 101. Schmidberger (2003), para. 71; Elliniki Radiophonia Tiléorasi Anonimi Etairia (1991), para. 41; Connolly (2001), para. 37; Roquette Frères (2002), para. 25.

Note 102. Opinion of Advocate General Poiares Maduro Case C-305/05 (Ordre des barreaux francophones et germanophones and Others), para. 42.

Note 103. supra note 92, at 377 . As the author rightly points out: '[t]he scope of application of the Charter is therefore the keystone which guarantees that the principle of conferral is complied with'.

Note 104. See, inter alia, Art. 6 ECHR, Art. 47 European Charter, and Art. 14 ICCPR.

Note 105. Art. 6 ECHR reads: 'In the determination of his civil rights and obligations or of any criminal charge against him, everyone is entitled to a fair and public hearing within a reasonable time by an independent and impartial tribunal established by law. Judgment shall be pronounced publicly but the press and public may be excluded from all or part of the trial in the interests of morals, public order or national security in a democratic society, where the interests of juveniles or the protection of the private life of the parties so require, or to the extent strictly necessary in the opinion of the court in special circumstances where publicity would prejudice the interests of justice.'

Note 106. 'Everyone charged with a criminal offence has the following minimum rights: (d) to examine or have examined witnesses against him and to obtain the attendance and examination of witnesses on his behalf under the same conditions as witnesses against him.'

Note 107. Beijer, A. \& Liefaard, T. (2011), at 30.

Note 108. Doorson and Others (1997). In Doorson the Court stated (para. 53) 'Against this background, principles of fair trial (...) require that in appropriate cases the interests of the defence are balanced against those of witnesses or victims called upon to testify.'

Note 109. Doorson and Others (1997), at para. 54. 'However, if the anonymity of prosecution witnesses is maintained, the defence will be faced with difficulties which criminal proceedings should not normally involve. Accordingly, the Court has recognised that in such cases Article 6 para. 1 taken together with Article 6 para. 3 (d) of the Convention (art. 6-1+6-3-d) requires that the handicaps under which the defence labours be sufficiently counterbalanced by the procedures followed by the judicial authorities'.

Note 110. P.S. (2001).

Note 111. P.S. (2001), at paras. 8-11.

Note 112. P.S. (2001), at paras. 29-32.

Note 113. S.N. (2002).

Note 114. S.N. (2002), at paras. 9-20.

Note 115. S.N. (2002), at paras. 53-4. 
Note 116. Bocos Cuesta (2005).

Note 117. Bocos Cuesta (2005), at paras. 9-45.

Note 118. Also see Kovač (2007). In this case the ECtHR found that a written transcript by an investigative magistrate could not adequately replace a testimony in court, which led to a violation of the right to examine witnesses.

Note 119. Kovač (2007), at paras. 72-4.

Note 120. A.L. (2009).

Note 121. A.L. (2009), at para. 6.

Note 122. A.L. (2009), at paras. 41, 45.

Note 123. A.L. (2009), at para. 44.

Note 124. Bykov (2009).

Note 125. Bykov (2009), at para. 33.

Note 126. Luca (2001), para. 40. The Court stated in this judgment that 'Where a conviction is based solely or to a decisive degree on depositions that have been made by a person whom the accused has had no opportunity to examine or to have examined, whether during the investigation or at the trial, the rights of the defence are restricted to an extent that is incompatible with the guarantees provided by Article 6.'

Note 127. See Al-Khawaja \& Tahery (2011); De Wilde, 2012:6.

Note 128. Al-Khawaja \& Tahery (2011), paras. 9-24, 128.

Note 129. Al-Khawaja \& Tahery (2011), at para. 154.

Note 130. Al-Khawaja \& Tahery (2011), at para. 158.

Note 131. Al-Khawaja \& Tahery (2011), at para. 156.

Note 132. Al-Khawaja \& Tahery (2011), at paras. 25-39.

Note 133. Al-Khawaja \& Tahery (2011), at para. 165.

Note 134. Al-Khawaja \& Tahery (2011), at para. 160.

Note 135. Al-Khawaja \& Tahery (2011), at paras. 161-2.

Note 136. Al-Khawaja \& Tahery (2011), at para. 119. Also see supra note 126.

Note 137. Al-Khawaja \& Tahery (2011), at para. 152.

Note 138. Al-Khawaja \& Tahery (2011), at para. 120.

Note 139. Directive 2012/29/EU, Art. 27(1).

\section{Copyrights}

Copyright for this article is retained by the author(s), with first publication rights granted to the journal.

This is an open-access article distributed under the terms and conditions of the Creative Commons Attribution license (http://creativecommons.org/licenses/by/3.0/). 